\title{
AKTSAR
}

ISSN 2622-5255 (online)

\section{Pengaruh Moralitas Individu, Asimetri Informasi, Efektivitas Pengendalian Internal, dan Keadilan Organisasi Terhadap Kecenderungan Kecurangan (Fraud) Akuntansi (Studi Empiris pada Badan Usaha Milik Daerah Kota Surakarta)}

\author{
Eskasari Putri \\ Universitas Muhammadiyah Surakarta \\ ep122@ums.ac.id \\ Wahyono \\ Universitas Muhammadiyah Surakarta \\ wahyonoums@gmail.com
}

ABSTRACT

This study aims to determine the effect of individual morality, information asymmetry, the effectiveness of internal control, and organizational justice on the tendency of accounting fraud on BUMD in Surakarta. The theories used in this study are the Triangle Fraud Theory, Agency Theory, and Moral Reasoning Theory. The population of this study is employees who work in the Regional Owned Enterprises in the Surakarta City area. This study sampled administrative staff at the BUMD Surakarta region. The sampling method in this study using purposive sampling method. The tests carried out include testing validity, reliability, classical assumptions, and multiple linear regression analysis. The results showed that information asymmetry, the effectiveness of internal controls, and organizational justice had a positive effect on fraudulent tendencies. While the variabels of individual morality negatively affect the tendency of fraud.

Keywords: Individual morality; Information asymmetry; Effectiveness of internal controls; Organizational justice; Fraudulent tendencies. 


\section{ABSTRAK}

Penelitian ini bertujuan untuk mengetahui pengaruh moralitas individu, asimetri informasi, efektivitas pengendalian internal, dan keadilan organisasi terhadap kecenderungan kecurangan (fraud) akuntansi pada Badan Usaha Milik Daerah (BUMD) di Surakarta. Teori yang digunakan dalam penelitian ini adalah Teori Fraud Triangel, Teori Keagenan, dan Teori Penalaran Moral. Populasi dari penelitian ini adalah karyawan yang berkerja di Badan Usaha Milik Daerah wilayah Kota Surakarta. Penelitian ini mengambil sampel staf administrasi pada BUMD wilayah Surakarta. Metode pengambilan sampel dalam penelitian ini dengan menggunakan metode purposive sampling. Pengujian yang dilakukan antara lain pengujian validitas, reliabilitas, asumsi klasik, dan analisis regresi linier berganda. Hasil penelitian menunjukkan bahwa asimetri informasi, efektivitas pengendalian internal, dan keadilan organisasi berpengaruh positif terhadap kecenderungan kecurangan (fraud). Sedangkan variabel moralitas individu berpengaruh negatif terhadap kecenderungan kecurangan (fraud).

Kata kunci: Moralitas individu; Asimetri informasi; Efektivitas pengendalian internal; Keadilan organisasi; Kecenderungan kecurangan (fraud).

\section{PENDAHULUAN}

Seiring dengan berkembangnya kompleksitas bisnis dan semakin terbukanya peluang usaha dan investasi menyebabkan risiko terjadinya kecurangan pada perusahaan semakin tinggi. Terjadinya kecenderungan kecurangan akuntansi (KKA) membuat organisasi atau lembaga yang dikelola menjadi rugi. Sebagai contoh, volume produktivitas organisasi melemah, belanja sosial organisasi semakin sedikit, kepercayaan masyarakat yang dilayani beralih ke organisasi lain, dan mitra kerja tidak selera lagi untuk tetap bekerja sama. Di sisi lain kasus KKA tidak terlepas dari pemberitaan media massa. Jika demikian yang terjadi, reputasi dan citra organisasi yang terbangun selama ini menjadi sulit untuk dijadikan daya saing dalam meraih persaingan pasar yang semakin tajam.

Kecurangan akuntansi sangat erat hubungannya dengan etika. Kecurangan akuntansi merupakan suatu tindakan ilegal. Menurut Prawira dkk. (2014), secara umum perilaku ilegal adalah bagian dari perilaku tidak etis, oleh karena itu ada hukum yang harus ditegakkan sebagai bagian dari usaha penegakkan standar moral. Penelitian dari Prawira dkk. (2014) menemukan bahwa etika dan lingkungan pengendalian akuntansi merupakan dua hal yang 
sangat penting terkait kecenderungan seseorang dalam melakukan kecurangan akuntansi.

Prawira dkk. (2014) menyatakan bahwa faktor integritas personal dalam fraud scale mengacu kepada kode etik personal yang dimiliki oleh tiap individu. Beberapa penelitian di bidang etika menggunakan teori perkembangan moral untuk mengobservasi dasar individu melakukan suatu tindakan. Salah satu yang sering digunakan adalah teori mengenai level penalaran moral Kohlberg. Mengetahui level penalaran moral seseorang akan menjadi dasar untuk mengetahui kecenderungan individu melakukan suatu tindakan tertentu, terutama yang berkaitan dengan dilemma etika, berdasarkan level penalaran moralnya. Prawira dkk. (2014) menyatakan bahwa kemampuan individu dalam menyelesaikan dilema etika dipengaruhi oleh level penalaran moralnya. Hasil penelitian Prawira dkk. (2014) menemukan bahwa semakin tinggi level penalaran moral individu akan semakin cenderung tidak berbuat kecurangan akuntansi.

Selain faktor rasionalisasi yang berkaitan erat dengan etika, faktor lain yang menjadi penyebab kecurangan akuntansi adalah faktor kesempatan. Kesempatan atau opportunity merupakan suatu kondisi yang memungkinkan seseorang bisa melakukan kecurangan. Kondisi tersebut sebenarnya dapat dikendalikan oleh perusahaan. Faktor-faktor yang dapat mempengaruhi terjadinya kondisi tersebut dalam lingkup entitas antara lain penegakan peraturan, keefektifan sistem pengendalian internal, dan asimetri informasi.

Menurut Prawira dkk. (2014) menyatakan bahwa pengendalian intern yang efektif mengurangi kecenderungan kecurangan akuntansi. Menurut Prawira dkk. (2014), pengendalian intern adalah suatu proses yang dijalankan oleh dewan komisaris, manajemen, dan personel lain entitas yang didesain untuk memberikan keyakinan memadai tentang pencapaian tiga golongan tujuan berikut ini: (1) Keandalan laporan keuangan, (2) Efektifitas dan efisiensi operasi, serta (3) Kepatuhan terhadap hokum dan peraturan yang berlaku. Kecurangan akan dilakukan jika ada kesempatan dimana seseorang harus memiliki akses terhadap aset atau memiliki wewenang untuk mengatur prosedur pengendalian yang memperkenankan dilakukannya skema kecurangan. Jabatan, tanggung jawab, maupun otorisasi memberikan peluang untuk terlaksananya kecurangan (Suprajadi, 2009) dalam Prawira dkk. (2014). Untuk meminimalisir peluang atau kesempatan seseorang untuk melakukan kecurangan maka diperlukan pengendalian internal yang efektif.

Menurut Ariani (2014) asimetri informasi adalah ketidakseimbangan informasi yang dimiliki oleh principal dan agen, ketika principal tidak memiliki informasi yang cukup tentang kinerja agen, sebaliknya agen memiliki lebih banyak informasi mengenai kapasitas diri, lingkungan kerja dan perusahaan secara keseluruhan. Jika semakin tinggi asimetri informasi, maka kecenderungan kecurangan akuntansi semakin meningkat.

Keadilan organisasi (organizational justice) yaitu keadilan organisasi sebagai penilaian personal mengenai standar etika dan moral dari pelaku manajerial. Apabila karyawan merasa adil dalam sebuah organisasi, maka 
tingkat kepuasannya akan tercapai dan mereka akan bekerja secara profesional.

Badan Usaha Milik Negara (BUMD) merupakan salah satu organisasi yang dimiliki oleh Pemerintah Daerah yang berkontribusi besar terhadap Pendapatan Asli Daerah (PAD). Tujuan dibentuknya BUMD adalah untuk melaksanakan pembangunan daerah melalui pelayanan jasa kepada masyarakat, penyelenggaraan kemanfaatan umum dan peningkatan penghasilan pemerintah daerah. Untuk mewujudkan tujuan dan berbagai sasaran dari BUMD, perlu ditentukannya dinamika perusahaan yang bersangkutan dan interaksi yang terjadi baik antara perusahaan dengan lingkungannya maupun antara satuansatuan kerja di dalam perusahaan tersebut. Badan akan mampu mencapai misi dan tujuan yang telah ditetapkan apabila kekuatan perusahaan melebihi kelemahan yang dimiliki. Mengingat dipandang cukup pentingnya peran BUMD khususnya sebagai salah satu sumber PAD di Daerah dan kasus kecurangan yang sering terjadi di sektor pemerintahan dan BUMD, maka BUMD dituntut agar lebih profesional dan lebih efisien dalam melaksanakan usahanya. Selain itu dilihat dari tujuan BUMD yaitu melayani kepentingan umum dan meningkatkan penerimaan daerah dalam PADnya, maka penelitian ini sangat penting dilakukan untuk mengetahui sejauh mana pengaruh moralitas individu, asimetri informasi dan efektivitas pengendalian internal terhadap kecenderungan kecurangan (fraud) akuntansi di masing-masing BUMD yang terdapat di Kota Surakarta.

Penelitian ini mengacu pada penelitian sebelumnya yang dilakukan oleh Prawira dkk. (2014) dengan menambah satu variabel independen yang digunakan yaitu Keadilan Organisasi. Penilaian keadilan dalam organisasi mempunyai dampak pada sikap dan reaksi seseorang (Setiawan dkk., 2015). Sedangkan dalam penelitian Prawira dkk. (2014) tidak ada variabel independen mempunyai pengaruh yang signifikan terhadap kecenderungan kecurangan akuntansi.

\section{Teori Fraud Triangel}

Teori Fraud Triangle yang dikembangkan oleh Zulkarnaen (2013), mengatakan bahwa fraud disebabkan oleh tiga faktor, yaitu: (1) Pressure atau tekanan, (2) Oportunity atau kesempatan, (3) Rationalization atau pembenaran. Penelitian ini cenderung menggunakan teori Fraud Triangle, karena variabel dalam penelitian ini merupakan suatu proksi dari adanya suatu tekanan, opportunity, dan rasionalitas sesuai dengan dasar teori Fraud Triangle.

Penelitian ini dilakukan dengan menggali persepsi para pegawai di instansi sektor pemerintahan untuk mengetahui kecenderungan terjadinya fraud di sektor pemerintahan dan faktor-faktor yang mempengaruhinya. Faktor-faktor ini terdiri dari keefektifan pengendalian internal, kepuasan kompensasi, kultur organisasi, perilaku tidak etis, gaya kepemimpinan, sistem pengendalian internal dan penegakan hukum. Dalam beberapa penelitian, ada beberapa hal yang terkait dengan tekanan (pressure) yaitu: ketidakpuasan kompensasi, persepsi keadilan organisatoris, penghasilan kurang, kebutuhan hidup yang tak tercukupi (Zulkarnaen, 2013). 
Pada penelitian kali ini peneliti memproksikan suatu Pressure (tekanan) dengan adanya kepuasan kompensasi dan gaya kepemimpinan yang didukung dengan teori Greenberg (1980) dalam Zulkarnaen (2013) tentang keadilan interaksional. Opportunity adalah peluang yang memungkinkan fraud terjadi. Biasanya disebabkan karena internal control suatu organisasi yang lemah, kurangnya pengawasan, dan penyalahgunaan wewenang. Rasionalisasi adalah pemikiran yang menjustifikasi tindakannya sebagai suatu perilaku yang wajar, yang secara moral dapat diterima dalam suatu masyarakat yang normal.

\section{Teori Keagenan}

Teori keagenan bermaksud memecahkan dua problem yang terjadi dalam hubungan keagenan. Salah satunya adalah problem yang muncul bila keinginan atau tujuan dari prinsipal dan agen bertentangan, dan juga disaat prinsipal merasa kesulitan untuk menelusuri apa yang sebenarnya dilakukan oleh agen. Teori keagenan juga menganalisis susunan kontraktual di antara dua atau lebih individu, kelompok, atau organisasi.

Salah satu pihak (principal) membuat suatu kontrak, baik secara implisit maupun eksplisit, dengan pihak lain (agent) dengan harapan bahwa agen akan bertindak/melakukan pekerjaan seperti yang diinginkan oleh prinsipal Ahriati (2015). Penelitian Ahriati (2015) menunjukkan bahwa semakin tinggi asimetri informasi yang terjadi maka semakin tinggi kecenderungan seseorang untuk melakukan kecurangan akuntansi. Sehingga sistem pengendalian internal harus berjalan secara efektif untuk menghilangkan asimetri informasi yang terjadi.

\section{Teori Penalaran Moral}

Mengetahui level penalaran moral seseorang akan menjadi dasar untuk mengetahui kecenderungan individu melakukan suatu tindakan tertentu, terutama yang berkaitan dengan dilema etika, berdasarkan level penalaran moralnya. Prawira dkk. (2014) menyatakan bahwa kemampuan individu dalam menyelesaikan dilema etika dipengaruhi oleh level penalaran moralnya. Hasil penelitian Prawira dkk. (2014) menemukan bahwa semakin tinggi level penalaran moral individu akan semakin cenderung tidak berbuat kecurangan akuntansi. Prawira dkk. (2014) menemukan bahwa semakin tinggi level moral individu akan semakin sensitif terhadap isu-isu etika. Selain faktor rasionalisasi yang berkaitan erat dengan etika, faktor lain yang menjadi penyebab kecurangan akuntansi adalah faktor kesempatan.

Kesempatan atau opportunity merupakan suatu kondisi yang memungkinkan seseorang bisa melakukan kecurangan. Kondisi tersebut sebenarnya dapat dikendalikan oleh perusahaan. Faktor-faktor yang dapat mempengaruhi terjadinya kondisi tersebut dalam lingkup entitas antara lain penegakan peraturan, keefektifan sistem pengendalian internal, dan asimetri informasi. 


\section{Perumusan Hipotesis}

\section{Pengaruh moralitas individu terhadap kecenderungan kecurangan (fraud) akuntansi}

Menurut Prawira dkk. (2014) dalam penelitiannya moralitas adalah sikap dan perbuatan baik yang betul-betul tanpa pamrih. Beberapa penelitian di bidang etika menggunakan teori perkembangan moral untuk mengobservasi dasar individu melakukan suatu tindakan. Salah satu yang sering digunakan adalah teori mengenai level penalaran moral Kohlberg. Mengetahui level penalaran moral seseorang akan menjadi dasar untuk mengetahui kecenderungan individu melakukan suatu tindakan tertentu, terutama yang berkaitan dengan dilema etika, berdasarkan level penalaran moralnya. Welton (1994) menyatakan bahwa kemampuan individu dalam menyelesaikan dilema etika dipengaruhi oleh level penalaran moralnya. Hasil penelitian Prawira dkk. (2014) menemukan bahwa semakin tinggi level penalaran moral individu akan semakin cenderung tidak berbuat kecurangan akuntansi.

Beberapa penelitian menunjukkan bahwa moralitas individu terbukti berpengaruh terhadap kecenderungan kecurangan (fraud) akuntansi. Seperti yang dilakukan oleh Prawira dkk. (2014) dan Ariani (2014). Berdasarkan uraian diatas maka penelitian ini mengajukan hipotesis berikut:

H1: Moralitas individu berpengaruh terhadap kecenderungan kecurangan (fraud) akuntansi.

\section{Pengaruh asimetri informasi terhadap kecenderungan kecurangan (fraud) akuntansi}

Menurut Fatun (2013) dalam Prawira dkk. (2014), Asimetri informasi merupakan keadaan dimana pihak dalam perusahaan mengetahui informasi yang lebih baik dibanding pihak luar perusahaan (stakeholder). Jika terjadi kesenjangan informasi antara pihak pengguna dan pihak pengelola, maka akan membuka peluang bagi pihak pengelola dana untuk melakukan kecurangan. Yang dimaksud kesenjangan informasi disini adalah perbedaan kuantitas informasi yang dimiliki oleh pengguna atau eksternal dan pihak internal pengelola keuangan. Pengelola memiliki informasi lebih banyak daripada eksternal sehingga menimbulkan peluang bagi pihak internal (pengelola keuangan) untuk memanipulasi laporan keuangan. Beberapa penelitian menunjukkan bahwa asimetri informasi terbukti berpengaruh terhadap kecenderungan kecurangan (fraud) akuntansi. Seperti yang dilakukan Prawira dkk. (2014) dan Ariani (2014).

Berdasarkan uraian diatas maka penelitian ini mengajukan hipotesis sebagai berikut:

H2: Asimetri Informasi berpengaruh terhadap kecenderungan kecurangan (fraud) akuntansi. 


\section{Pengaruh efektivitas pengendalian intern terhadap kecenderungan} kecurangan (fraud) akuntansi

Efektivitas pengendalian internal adalah suatu proses yang dijalankan oleh dewan komisaris, manajemen, dan personel lain entitas yang didesain untuk memberikan keyakinan memadai tentang pencapaian tiga golongan tujuan berikut ini keandalan laporan keuangan, efektifitasan dan efisiensi operasi, serta kepatuhan terhadap hokum dan peraturan yang berlaku

Prawira dkk. (2014) yang menunjukkan bahwa pelaksanaan SPI berhubungan dengan tingkat kecurangan atau kepatuhan terhadap peraturan dalam membuat laporan akuntabilitas. Kualitas SPI berpengaruh pada tes transaksi dan tes detail terhadap neraca, aktivitas deteksi fraud, dan kejadian fraud. Semakin sesuai SPI dengan tujuannya semakin sederhana deteksi fraud perlu dilakukan. Artinya jika sistem penngendalian internal dalam instansi sudah berjalan efektif, maka kemungkinan kecurangan (fraud) yang terjadi juga akan semakin kecil. Prawira dkk. (2014) juga menegaskan bahwa jika bentuk penekanan untuk mengikuti SPI diperhatikan secara khusus, akan mengurangi fraud.

Beberapa penelitian menunjukkan bahwa efektivitas pengendalian intern terbukti berpengaruh terhadap kecenderungan kecurangan akuntansi. Seperti yang dilakukan oleh Prawira dkk. (2014), Putri (2014), Zulkarnain (2014), dan Adinda (2015).

Berdasarkan uraian di atas maka peneliti ini mengajukan hipotesis sebagai berikut:

H3: efektivitas pengendalian Intern berpengaruh terhadap kecenderungan kecurangan (fraud) akuntansi.

\section{Pengaruh keadilan organisasi terhadap kecenderungan kecurangan (fraud) akuntansi}

Keadilan organisasi adalah istilah untuk mendeskripsikan keamarataan atau keadilan pada perusahaan yang berfokus bagaimana para pekerja menyimpulkan apakah mereka diperlakukan secara adil dalam pekerjaannya dan bagaimana kesimpulan tersebut kemudian mempengaruhimvariabel lain yang berhubungan dengan pekerjaan.

Dengan adanya keadilan dalam perusahaan kecurangan akan berkurang karena para karyawan akan merasa puas terhadap apa yang dikerjakan dengan hasil yang diperoleh. Setiawan (2015) dan Sumbayak (2017). Beberapa penelitian menunjukkan bahwa keadilan organisasi terbukti berpengaruh terhadap kecenderungan (fraud) akuntansi. Seperti yang dilakukan Setiawan (2015).

Berdasarkan uraian diatas, maka penelitian ini mengajukan hipotesis sebagai berikut:

H4: keadilan organisasi berpengaruh terhadap kecenderungan kecurangan (fraud) akuntansi. 


\section{METODE}

Penelitian ini didesain survei dengan responden seluruh karyawan yang bekerja di BUMD Surakarta. Jenis penelitian ini adalah penelitian kuantitatif. Dengan pengujian hipotesis. Penelitian kuantitatif adalah penelitian yang menekankan pada pengujian teori-teori melalui pengukuran variabel-variabel penelitian. Tujuan penelitian ini adalah menguji pengaruh moralitas individu, asimetri informasi, keefektifan pengendalian internal, dan keadilan organisasi terhadap kecenderungan kecurangan (fraud) akuntansi. Periode penelitian direncanakan bulan Oktober 2017 sampai dengan Desember 2017.

Populasi dari penelitian ini adalah karyawan yang berkerja di Badan Usaha Milik Daerah wilayah Kota Surakarta. Sampel menurut Sugiyono (2014:116) adalah bagian dari jumlah dan karakteristik yang memiliki oleh populasi tersebut. Penelitian ini mengambil sampel staf administrasi pada BUMD wilayah Surakarta. Metode pengambilan sampel dalam penelitian ini dengan menggunakan metode purposive sampling. Metode purposive sampling merupakan teknik penentuan sampel dengan pertimbangan tertentu. (Sugiyono: 2014)

Jenis data yang dipakai dalam penelitian ini adalah data primer.data. Data primer diperoleh dengan menggunakan daftar pertanyaan yang telah terstuktur dengan tujuan untuk mengumpulkan informasi dari karyawan yang bekerja pada BUMD wilayah Surakarta sebagai responden dalam penelitian ini. Sumber data dalam penelitian ini adalah skor masing-masing indikator variabel diperoleh dari pengisian kuesioner yang telah dibagi kepada karyawan pada BUMD wilayah Kota Surakarta.

Data yang diperlukan dalam penelitian ini adalah data mengenai pengaruh moralitas individu, asimetri informasi, efektivitas pengendalian internal dan keadilan organisasi terhadap kecenderungan kecurangan (fraud) akuntansi. Pengumpulan data dalam penelitian ini dilakukan dengan menggunakan kuesioner (angket) yang diberikan secara langsung kepada setiap BUMD yang bersedia menjadi objek penelitian dalam lingkungan bagian administratif. Pengumpulan data dilakukan selama kurun waktu 3 bulan yang dimulai bulan Oktober 2017-Desember 2017.

\section{HASIL DAN PEMBAHASAN}

\section{Koefisien Regrasi Berganda}

Model estimasi sebagai berikut:

$Y=12,585-0,006 X 1+0,113 X 2+0,200 X 3+0,367 X 4$

Keterangan:

Y : Kecurangan

X1: Moralitas Individu

X2: Asimetri Informasi

X3: Efektivitas Pengendalian Internal

X4: Keadilan Organisasi 
Dari persamaan di atas dapat dijelaskan bahwa :

1. Nilai konstanta sebesar 12,585 mengindikasikan bahwa jika variabel independen yaitu moralitas individu, asimetri informasi, efektivitas pengendalian internal, dan keadilan organisasi adalah nol maka nilai kecurangan adalah sebesar konstanta 12,585

2. Nilai koefisien regresi moralitas individu (X1) sebesar $-0,006$. Hal ini menandakan bahwa setiap penurunan satu satuan moralitas individu akan meningkatkan kecurangan sebesar 0,006. Dengan asumsi asimetri informasi, efektivitas pengendalian internal, dan keadilan organisasi adalah nol.

3. Koefisien asimetri informasi (X2) sebesar 0,113 dimana setiap peningkatan asimetri informasi satu satuan akan mengakibatkan peningkatan pada kecurangan akuntansi sebesar 0,113. Dengan asumsi moralitas individu, efektivitas pengendalian internal, dan keadilan organisasi adalah nol.

4. Nilai koefisien regresi efektivitas pengendalian internal (X3) sebesar 0,200 dimana setiap peningkatan efektivitas pengendalian internal satu satuan akan mengakibatkan peningkatan pada kecurangan akuntansi sebesar 0,113. Dengan asumsi moralitas individu, asimetri informasi, dan keadilan organisasi adalah nol.

5. Nilai koefisien regresi keadilan organisasi (X4) sebesar 0,367 dimana setiap peningkatan keadilan organisasi satu satuan akan mengakibatkan peningkatan pada kecurangan akuntansi sebesar 0,113. Dengan asumsi moralitas individu, asimetri informasi, dan efektivitas pengendalian internal adalah nol.

\section{Uji Hipotesis}

Moralitas individu berpengaruh terhadap kecenderungan kecurangan (fraud) akuntansi. Nilai $\beta$ dengan arahnya negatif sebesar $-0,006$. hal ini menunjukkan bahwa moralitas individu berpengaruh signifikan negatif terhadap kecurangn (fraud) akuntansi, sehingga hipotesis kedua pertama diterima.

Asimetri Informasi berpengaruh terhadap kecenderungan kecurangan (fraud) akuntansi Nilai $\beta$ dengan arahnya positif sebesar 0,113. hal ini menunjukkan bahwa asimetri informasi berpengaruh signifikan positif terhadap kecurangn (fraud) akuntansi, sehingga hipotesis kedua pertama diterima.

Efektivitas pengendalian Internal berpengaruh terhadap kecenderungan kecurangan (fraud) akuntansi. Nilai $\beta$ dengan arahnya positif sebesar 0,200. hal ini menunjukkan bahwa efektivitas pengendalian internal berpengaruh signifikan positif terhadap kecurangn (fraud) akuntansi, sehingga hipotesis kedua pertama diterima.

Keadilan Organisasi berpengaruh terhadap kecenderungan kecurangan (fraud) akuntansi. Nilai $\beta$ dengan arahnya positif sebesar 0,367. hal ini menunjukkan bahwa keadilan organisasi berpengaruh signifikan positif 
terhadap kecurangn (fraud) akuntansi, sehingga hipotesis kedua pertama diterima.

\section{SIMPULAN}

Penelitian ini bertujuan untuk melihat pengaruh moralitas individu, asimetri informasi, efektivitas pengendalian internal, dan keadilan organisasi terhadap kecurangan (fraud) akuntansi pada Badan Usaha Milik Daerah kota Surakarta. Berdasarkan hasil penelitian dan pengujian hipotesis yang telah dilakukan, maka hasil penelitian dapat disimpulkan bahwa Moralitas individu berpengaruh signifikan negatif terhadap kecurangan (fraud) akuntansi pada Badan Usaha Milik Daerah kota Surakarta. Asimetri informasi berpengaruh signifikan positif terhadap kecurangan (fraud) akuntansi pada Badan Usaha Milik Daerah kota Surakarta. Efektivitas pengendalian internal berpengaruh signifikan positif terhadap kecurangan (fraud) akuntansi pada Badan Usaha Milik Daerah kota Surakarta. Keadilan organisasi berpengaruh signifikan positif terhadap kecurangan (fraud) akuntansi pada Badan Usaha Milik Daerah kota Surakarta.

\section{DAFTAR PUSTAKA}

Adinda, Y. M., Ikhsan Sukardi. (2015). Faktor yang Mempengaruhi terjadinya kecurangan (Fraud) di Sektor Pemerintah Kabupaten Klaten. Acounting Analysis Journal. Vol. 4 (3).

Ahriarti, Deni, Basuki, Prayitno, Widiastuty, Erna. (2015). Analisis Pengaruh Sistem Pengendalian Internal, Asimetri Informasi, Perilaku Tidak Etis dan Kesesuaian Kompensasi terhadap Kecenderungan Kecurangan Akuntansi pada Pemerintah Daerah Kabupaten Lombok Timur. Jurnal Infestasi, Vol 11, No 1: 41-55.

Aranta, Petra Yulia. (2013). Pengaruh Moralitas Aparat dan Asimetri Informasi terhadap Kecenderungan Kecurangan Akuntansi (Studi Empiris Pemerintah Kota Sawahlunto). Skripsi. Universitas Negri Padang.

Ariani, K. S, Herawati, N. T, dan Musmini. (2014). Analisis Pengaruh Moralitas Individu, Asimetri Informasi, dan Keefektifan Sistem Pengendalian Internal terhadap kecenderungan Akuntansi di PDAM Kabupaten Bangli. Jurnal Akutansi Program S1, Volume 2, No 1.

Fachrunisa, Aisah. (2015). Pengaruh Pengendalian Internal, Keadilan Distributif, Keadilan Prosedural, dan Budaya Etis Terdahap Kecenderungan Kecurangan (Fraud) Akuntansi (Studi Empiris pada SKPD Kabupaten Kampar). Jurnal Fekon, Volume 2, No 2.

Herman, Lisa Amelia. (2013). Pengaruh Keadilan Organisasi dan Sistem Pengendalian Intern terhadap Kecurangan (Studi Empiris pada Kantor Cabang Utama Bank Pemerintah di Kota Padang). Skripsi. Universitas Negeri Padang. 
Najahningrum, Anik Fatun. (2013). FaktorFaktor Yang Mempengaruhi Kecenderungan Kecurangan (Fraud): Persepsi Pegawai Dinas Provinsi DIY. Skripsi. Universitas Negeri Semarang.

Prawira, M. D., Herawati, N. T., dan Darmawa, N. A. S., (2014). Pengaruh Moralitas Individu, Asimetri Informasi, dan Efektivitas Pengendalian Internal terhadap Kecenderungan (Fraud) Akuntansi (Studi Empiris pada Badan Usaha Milik Daerah Kabupaten Buleleng). Jurnal Akuntansi Program S1, Volume 2 No 1.

Putri, A. A. P. A. (2014). Pengaruh Keefektifan Pengendalian Internal dan Kepuasan Kerja Terhadap Kecenderungan Kecurangan Akuntansi pada Dinas Pendapatan Pengelola Keuangan Aset Daerah Istimewa Yogyakarta. Jurnal Nominal, Volume III No 1.

Setiawan, M. S., Adiputra, M. A. P., dan Yuniarta, G. A. (2015). Pengaruh Sistem Pengendalian Intern, Asimetri Informasi, dan Keadilan Organisasi terhadap Kecurangan (Fraud) (Studi Empiris pada Bank Perkreditan Rakyat se-Kabupaten Buleleng). Jurnal Akuntansi Program S1, Volume 3, No1.

Sugiyono. (2014). Metode Penelitian Kunatitatif, Kualitatif dan RED. Alfabeta, Bandung.

Sumbayak, Jelfani Saragih. (2017). Pengaruh Keadilan organisasi, Sistem Pengendalian Intern, Komitmen Organisasi dan Gaya Kepemimpinan terhadap Kecurangan (Fraud) (Studi Empiris pada Kantor Cabang Utama Perusahaan Leasing di Kota Pekan Baru). JOM Fekon, Volume 4, No 1.

Yuliana, Anisya. (2016). Pengaruh Keadilan Organisasi, Sistem Pengendalian Intern, dan Organisasi terhadap Kecurangan (Fraud) (Studi Empiris pada kantor cabang utama bank syariah di kota Pekan Baru). JOM Fekon, Volume 3, No 1.

Zulkarnain, M. R. (2013). Analisis Faktor yang Mempengaruhi terjadinya Fraud pada Dinas Kota Surakarta. Acounting Analisis Journal. Vol. 2 (2). 
Eskasari Putri \& Wahyono

Halaman ini sengaja dikosongkan 